\title{
Нордический классицизм 1910-1930 годов
}

\author{
П.О.Цветкова, МГХПА им. С.Г. Строганова, Москва
}

Статья посвящена описанию архитектурного стиля «нордический классицизм» на примере творчества зодчих Дании, Швеции, Норвегии и Финляндии первой трети XX века. Специфические особенности нового этапа прочтения классических законов создали неповторимый язык архитектурных форм, заложив фундамент для дальнейшего развития скандинавской школы. Рассматривается взаимосвязь с архитектурой итальянского Возрождения и, в частности, степень влияния проектной культуры А. Палладио и классического наследия Возрождения в целом. Стиль, ставший интерлюдией между национальным романтизмом и модернизмом, рассматривается на фактических примерах творческой практики таких архитекторов, как Х. Кампманн, Г. Асплунд, С. Леверенц, А. Якобсен, А. Аалто, К. Готтлоб, Р. Остберг и других мастеров. В статье освещены принципиальные основы появления движения нордического классицизма и его социокультурное значение. Архитектурные памятники, данного направления, раскрываются во взаимосвязи с общим возрождением интереса к классическому наследию в европейских странах в 1910-1920-е годы. Эклектичное по своей сути движение, оказалось стартовым этапом для появления архитектуры функционализма и всего североевропейского рационального архитектурного языка XX века. В статье прослеживается эволюция стиля в различных его проявлениях.

Ключевые слова: фасад, нордический классицизм, палладианство, Скандинавия, стиль, архитектор, эволюция, влияние.

\section{Nordic Classicism of 1910-1930}

P.O.Tsvetkova, Stroganov Academy, Moscow

The article is devoted to the description of the architectural style of Nordic classicism on the example of the creativity of architects from Denmark, Sweden, Norway, and Finland in the first third of the XX century. The specific features of the new stage in the interpretation of classical laws created a unique language of architectural forms, laying the foundation for the further development of the Scandinavian school. The relationship with the architecture of the Italian Renaissance and, in particular, the degree of influence of A. Palladio's design culture is considered. The style, which has become an interlude between national romanticism and modernism, is considered on actual examples of creative practice, such as architects $H$. Kampmann, G. Asplund, S. Leverenz, A. Jacobsen, A. Aalto, K. Gottlob, R. Ostberg, and other masters.
Keywords: facade, Nordic classicism, palladianism, Scandinavia, style, architect, evolution, influence.

Нордический классицизм - общее название архитектурного периода между 1910-ым и 1930-ыми годами в скандинавских странах (Швеция, Дания, Норвегия и Финляндия). Это время разработки идей классицистического архитектурного наследия, базировавшегося на палладианской традиции. В 1980-х годах в научный оборот плотно вошло определение движения - «Нордический классицизм» ${ }^{1}$, характеризующий максимальное возвращение к образной системе строя именно классической архитектуры по типу развития архитектуры итальянского Возрождения. Феномен его появления был широко исследован национальным искусствознанием скандинавских стран. Сам стиль стал продолжением поисков национального романтизма, в некоторых аспектах захватил отдельные веяния модерна, шёл параллельно с югендстилем, а по образным решениям приближался к функционализму. Сухой, ясный и рациональный язык этого стиля стал логичным следствием особенностей классицизма XVII-XIX веков в скандинавских странах. Развитие нордического классицизма 1910-го-1930-х годов не было изолированным явлением, оно отталкивалось от классических традиций, уже существовавших в скандинавских странах, и от новых идей, развивавшихся немецкоязычных культурах. Таким образом, нордический классицизм можно охарактеризовать как сочетание прямых и косвенных влияний неоклассицизма, а также ранних проявлений модернизма, проявившегося впервые в работах Немецкой ассоциации художников, архитекторов, дизайнеров и промышленников (Deutscher Werkbund), особенно представленных на их выставке 1914 года, и движения «Новый дух искусства» (Esprit Nouveau) середины 1920-х годов. Архитекторы использовали и теоретическую программу Ле Корбюзье. Модернистское влияние выходи-

${ }^{1}$ Нет точных данных, кто именно из исследователей закрепил за движением его нынешнее название. Но в научно-исследовательских статьях 1970-1990 годов это определение является устойчивым (работы подробно представлены в библиографии к статье). Иногда явление получает сходные определения, такие как - Североевропейский неоклассицизм, нордицизм в архитектуре, архитектура неоклассики в Скандинавских странах 1910-е-1930-е годы и другие. Однако наиболее близким к самой сути движения определением является «Нордический классицизм», поскольку именно оно базируется на идее, лежавшей в основе философского и культурного подтекста всего архитектурного направления, а именно - характерная для этого времени доктрина гипотетического превосходства нордического (арийского) расового типа и его культурных возможностей. 
ло за рамки простой эстетики: урбанизация была связана с современными строительными технологиями и введением правил как в строительстве, так и в городском планировании, и, более того, с ростом социальных изменений левого толка, что привело в свою очередь к изменению политической идеологии. Кроме того, другие страны Северной Европы, за исключением Финляндии, избежали участия в Первой мировой войне, что позволило продолжить контакты с другими европейскими странами и культурное развитие. Неучастие в войне привело к росту благосостояния северных стран и к активному социальному строительству больниц [например, больница Бекомберга в западном Стокгольме (К. Вестман, 1927-1935)], школы [например, школа Фридхемплана, Стокгольм (Г.А. Нильссон, 1925-1927)], типовые проекты недорогого жилья [например, город-сад Пуу-Капюля, Хельсинки (М. Вяликангасом, 1920-1925)], Морской музей в Стокгольме (Р. Остберг, 1931-1934) и др. В этом стиле появлялись и частные постройки, дома и особняки. Считается, что 1930-й год стал конечной точкой нордического классицизма, потому что это был год международной Стокгольмской выставки, проекты большей части павильонов и самой выставки созданы Г. Асплундом и С. Леверенцем. Итогом выставки стало всеобщее изменение архитектурного курса в скандинавских странах на использование вошедший в моду модернизм.

Некоторые из архитекторов данного направления достигли кульминации своей карьеры уже в период распространения национально романтического стиля, но их последние работы были в стиле нордического классицизма (например, К. Вестман), в карьере других именно период нордического классицизма стал самым ярким (например, И. Тенгбом и Р. Остберг), самые молодые архитекторы, стилистически примкнувшие к движению в ранних проектах, стали затем знаменитыми модернистами (например, А. Якобсен, А. Аалто и С. Маркелиус). В этот период интенсивного культурного обмена между северными странами большая часть архитекторов работали по всей Скандинавии. Шведский историк Хенрик 0 . Андерсон определил это время как «архитектуру демократии и культурного обмена».

Интерес к нордическому классицизму, особенно в его наиболее палладианской форме, возник в конце 1970-х и начале 1980-х годов в разгар постмодернизма, когда критики и историки архитектуры искали исторические прецеденты для понимания творчества таких архитекторов как Майкл Грейвс, Леон Криер и Роберт Стерн. Нордический классицизм и стал тем самым прецедентом, на примере которого возможно было осуществить стилистическое сравнение. В таких оригинальных объектах, как здание кинотеатра «Скандия» («Scandia») Г. Асплунда в Стокгольме (1924), вилла «Снельман» в Юрсхольме (1917-1918) и Стокгольмская публичная библиотека (1920-1928) ярко проявились основополагающие черты всего движения. Искусствоведами были установлены несколько причин, объясняющих появление и расцвет нордического классицизма. Начало положила классическая традиция, основанная на архитектуре абсолютизма, то есть классических архитектурных символах власти шведской и датской монархий. Этот же исторический период воспринимался как своеобразное возрождение стран, их укрепление на международной арене. Вполне логично, что после периода национального романтизма архитекторы пришли к трансляции эстетических символов эпохи палладианского классицизма как времени национального возрождения и крепкой монархической власти. Концепция нового социального восприятия человека отчасти базировалась на философии гуманизма, поэтому архитектурное возрождение идеалов ренессанса, пусть и в трактовке XVIII-XIX веков, воспринималось достаточно убедительно. Однако в практике нордических классицистов произошло некоторое упрощение классицизма. Этому способствовали несколько причин: первая из них - работа Ю. Н. Л. Дюрана в Политехнической школе Парижа в начале XIX века. Он пытался рационализировать язык и законы построения классицистической композиции, допуская при этом простые адаптированные решения. Эти работы распространились, проникнув в немецкую культуру, в форме романтического классицизма в работах Ф. Гилли и К.Ф. Шинкеля. Вторая причина - это окончательная расчистка построек в Помпеях, где было выявлено использование яркого цвета в римской архитектуре - аспект, который в некоторой степени был забыт в эпоху Возрождения, но стал решающим для новой архитектуры, зачастую использовавшей окрашивание объектов в активные цвета. Кроме римской архитектуры, в начале $X X$ века активно исследовали Египет и Грецию, что привнесло монументальные формы (от египетской архитектуры) и яркие мотивы архаики (Греция). Эти аспекты были включены и продолжены в нордическом классицизме.

Неоклассицизм пришел в Финляндию через Швецию как универсальный язык архитектуры, но к концу XIX века стал ассоциироваться с политическим угнетением и отсутствием независимости. Вместе с возникновением сепаратистских настроений в Финляндии и Норвегии бурно развивалась национальная романтическая архитектура - местный вариант стиля модерн, создающий почву для националистических мифов. Нордический классицизм, пришедший позднее, был противодействием национальному романтизму и эклектизму в целом; он воплощал движение к универсализму, интернационализму и упрощению. Многие из архитекторов, которые практиковали в нордическом классическом стиле, совершали паломничества в северную Италию для изучения архитектуры А. Палладио. Важным оказалось влияние немецких и австрийских критиков стиля модерн, в частности Г. Мутезия, который в 1907 году основал «Немецкую ассоциацию художников, архитекторов, дизайнеров и промышленников» (Deutscher Werkbund), Г. Тессенова и П. Беренса, А. Лосса.

Одновременно развитие нордического классицизма стало базисом, на котором произошло зарождение модернизма в северных странах. Демонстрацией эволюционного перехода от нордического классицизма к чистому функциона- 
лизму является проект А. Аалто ${ }^{2}$ для библиотеки в Выборге (1927-1935) (рис. 1). Первый проект, с течением времени, был полностью переделан и превратился в строго функционалистский.

В Дании нордический классицизм впервые проявляется в работах архитектора Х. Кампманна ${ }^{3}$. Первоначально он был одним из последовательных сторонников национального романтического стиля, в дальнейшем перешёл к стилю нордический классицизм, став одним из его главных популяризаторов. Одна из его наиболее заметных работ - комплекс зданий полицейского управления в Копенгагене (1918-1922) (рис. 2). Построенный в неоклассическом стиле, он занимает целый квартал города. Будучи на протяжении десяти лет (1908-1918) профессором архитектуры на кафедре в Королевской датской академии изящных искусств, Х. Кампманн читал лекции по великой архитектуре древнего мира, особенно по визуальным эффектам греческого храма. Эти знания он воспроизводил в своих проектах. Мегаломания архитектуры древнего мира повлияла на создание проекта полицейского управления. Классические формы ложились на гигантский объём постройки, тем самым став декоративным решением фасада, утратив своё изначальное конструктивное значение. Архитектор проектировал частные виллы, художественные музеи, коммерческие здания, церкви, а также небольшие государственные здания, например, почтовые отделения. Во всех своих работах 1920-го-1930-х годов он остаётся верным общим принципам нордического классицизма, хотя иногда интерпретирует их в соединении с экспериментальными масштабами сооружений.

Продолжением разработки идей нордического классицизма в Дании можно считать творчество К. Фискера ${ }^{4}$ - архитектора, дизайнера и педагога. Он известен своими многочисленными проектами типовой жилой застройки в Копенгагене и окрестностях. Пик карьеры архитектора пришелся на период датского функционализма (Датская академия в Риме, 1956), хотя начинал он в стиле нордического классицизма. Разработка новых жилых районов и типов доступного жилья была важной темой в архитектуре 1910-х - 1930-х годов, её также разрабатывал архитектор К. Готтлоб5 (например, общежитие датских студентов в Париже, 1929). В области проектирования жилых массивов выделяется творчество финского архитектора Я. Таучера ${ }^{6}$. Среди его первых проктов, выполненных совместно с коллегами Г. Каянусом и П. Бломштедтом в 1910-е годы, были скромные дома на одну семью, спроектированные в пригороде Хельсинки Кулосаари. В Хельсинки ощущалась острая нехватка доступного жилья, и Я. Таучер специализировался на подобных проектах застройки. Таковы первый многоквартирный дом для больных туберкулёзом на улице Ловийсанкату (1924) и дома для рабочих на улице Макеланкату под номерами 37-43 (1925). Центр обучения взрослых (1927) в стиле нордического классицизма (также совместно с П.Э. Бломштедтом).

Применение итальянских мотивов в архитектуре стали особенно модными в Дании в эпоху эклектики и модерна, ассо-

${ }^{2}$ А. Аалто (1898-1976), финский архитектор и дизайнер. Его работы включают объекты архитектуры, мебель, текстиль и изделия из стекла, разрабатывал проекты скульптуры.

${ }^{3}$ Х. Кампманн (1856-1920) - датский архитектор, профессор кафедры архитектуры Королевской датской академии художеств, инспектор государственных строений в Ютландии. Ездил в несколько образовательных поездок в Италию, Францию, Грецию и Швецию.

${ }^{4}$ К. Фискера (1893-1965), датский архитектор.

${ }^{5}$ К. Готтлоб (1887-1976), датский архитектор. Профессор архитектуры Королевской датской академии художеств. В 1930-х годах проектировал мебель и фурнитуру. Он также разработал мебель для датского павильона на Всемирной выставке 1925 года в Париже, которая была успешно выполнена краснодеревщиком А. Дж. Иверсеном, с которым он работал в течение ряда лет.

${ }^{6}$ Я. Таучер (1886-1941) - финский архитектор, стал известен в первые десятилетия XX века благодаря работам в стиле нордического классицизма. После 1930-х обратился к функционализму. В 1923 году занял должность главного городского архитектора Хельсинки.

7 П. Бломштедт (1900-1935), финский архитектор, был потомственным зодчим. Работал в стиле северного классицизма, а затем обратился к функционализму.

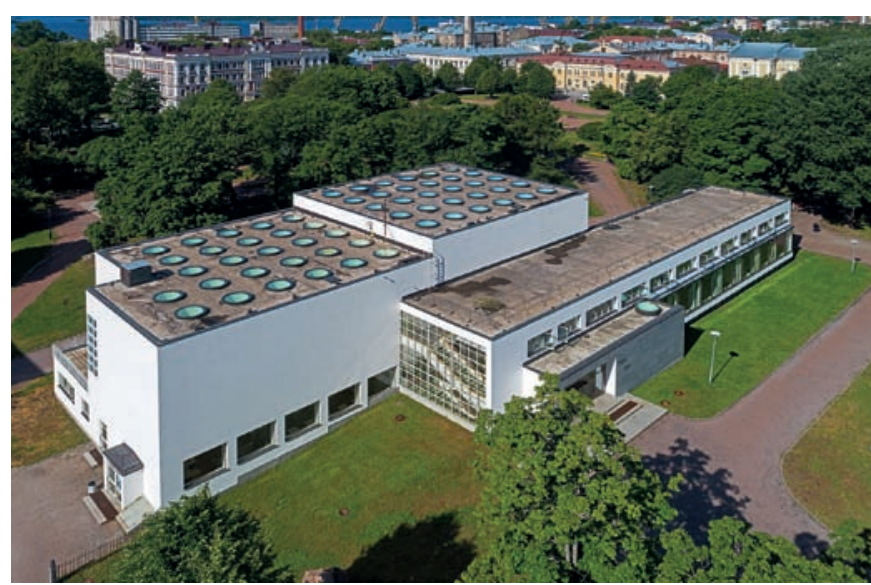

Рис. 1. Россия. Выборг. Городская библиотека. А. Аалто. 1927-1930. Фото из открытых источников сети интернет

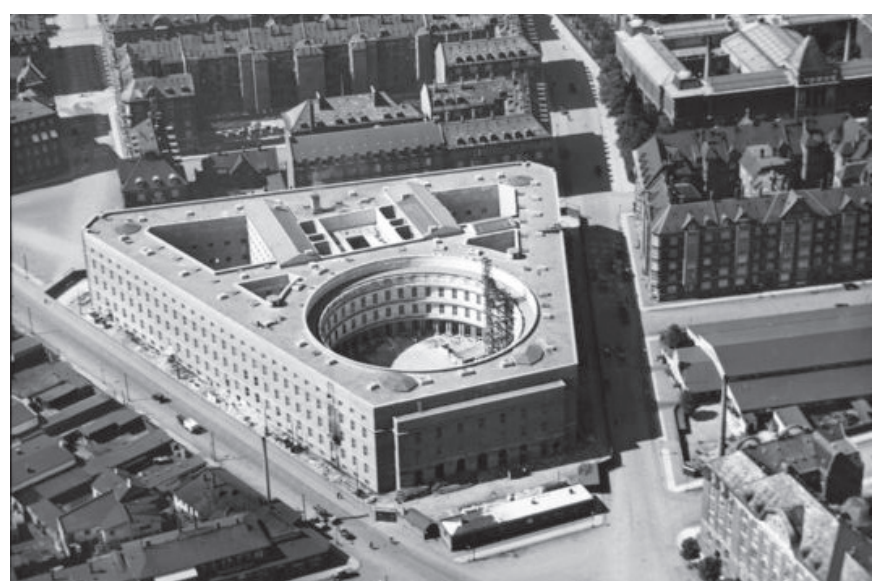

Рис. 2. Дания. Копенгаген. Полицейскоеуправление. Х. Кампманн. 1918-1920. Фото из открытых источников сети интернет 
циировать себя с героями эпохи Возрождения было приятной возможностью. Проявлялось это иногда в самых неожиданных постройках: например, в проекте крематория в Копенгагене (1905-1906) (рис. 3) использованы палладианские традиции, круглая в плане постройка, накрыта куполом. На фасаде портик, отдалённо направляющий визуальные ассоциации в сторону римского Пантеона и семейной усыпальницы Темпьетто Барбаро на вилле Барбаро в Мазер (А. Палладио). Автор проекта архитектор X. Якобсен ${ }^{8}$, открыто декларировал своё творчество, как имеющее корни в творчестве А. Палладио, и назвал себя «последним итальянцем в датской архитектуре».

Вместе с ростом экономики в скандинавских странах активно отстраиваются здания заводов и фабрик. Фасад здания завода «Туборг» (1923, архитектор С. Рисом9) (рис. 4), например, выполнен в духе лучших образцов сурового классицизма Голландии, гигантские пилястры максимально упрощены, не имеют капителей, пространство между ними занято окнами. Над кубическим объёмом здания, которое выглядит внушительным и одновременно лёгким благодаря большой площади остекления, возвышается башня с балконом, имеющим круговой обход (отсылка к архитектуре голландских и датских ратуш XVII-XVIII веков). Цокольный этаж - рустованный.

Финским нордическим классицистом был и У. Ульберг ${ }^{10}$. Его проекты охватывают период от так называемого нордического классицизма 1920-х годов к функционализму 1930-х. Считается ведущим архитектором периода скандинавского классицизма и первым, кто представил функционализм в Выборге ${ }^{11}$. Одной из первых построек У. Ульберга, выполненных в данном стиле, стала гостиница при здании редакции «Карельской типографии» (1925-1929) в Выборге. Семиэтажное здание с кирпичным фасадом, расчленённым пилястрами гигантского ордера на всю высоту до карниза. Вертикальный ритм пилястр смягчён арочными заполнениями промежутков между ними (рис. 5). В карниз врезаются окна последнего этажа, что в совокупности является своеобразным воплощением идеи капители над всем зданием. После 1930 года архитектор вступает в свой «белый период», создавая проекты на стыке идей нордического классицизма и функ-

${ }^{8}$ Х. Якобсен (1876-1960), датский архитектор, изучал архитектуру Италии, был увлечён творчеством Микеланджело.

${ }^{9}$ С. Рисом (1880-1971), закончил Технический университет Дании, позже поступил в Королевскую датскую академию изящных искусств, где получил степень в области архитектуры в 1909 году. Работал в Ассоциации, занимавшейся вопросами сохранения исторических памятников и в 1906 году провёл исследование древней датской архитектуры. В 1907 году он работал в качестве одного из руководителей исследований и ремонта старых гранитных церквей в Ютландии. Учился в Афинах, где участвовал в раскопках.

${ }^{10}$ У. Ульберг (1879-1944), финский архитектор, уроженец Выборга, получил образование в Хельсинки, затем вернулся в родной город, где создал большинство своих построек.

${ }^{11}$ Выборг (б. Viipuri) принадлежал до 1809 года королевству Швеции. В период 1809-1917 годов был частью автономного Великого княжества Финляндского. Это был второй по величине город независимой Финляндии по состоянию на 1917 год. Был завоёван Красной Армией в 1940 году, а затем, после 1944-го вошёл в состав Советского Союза.

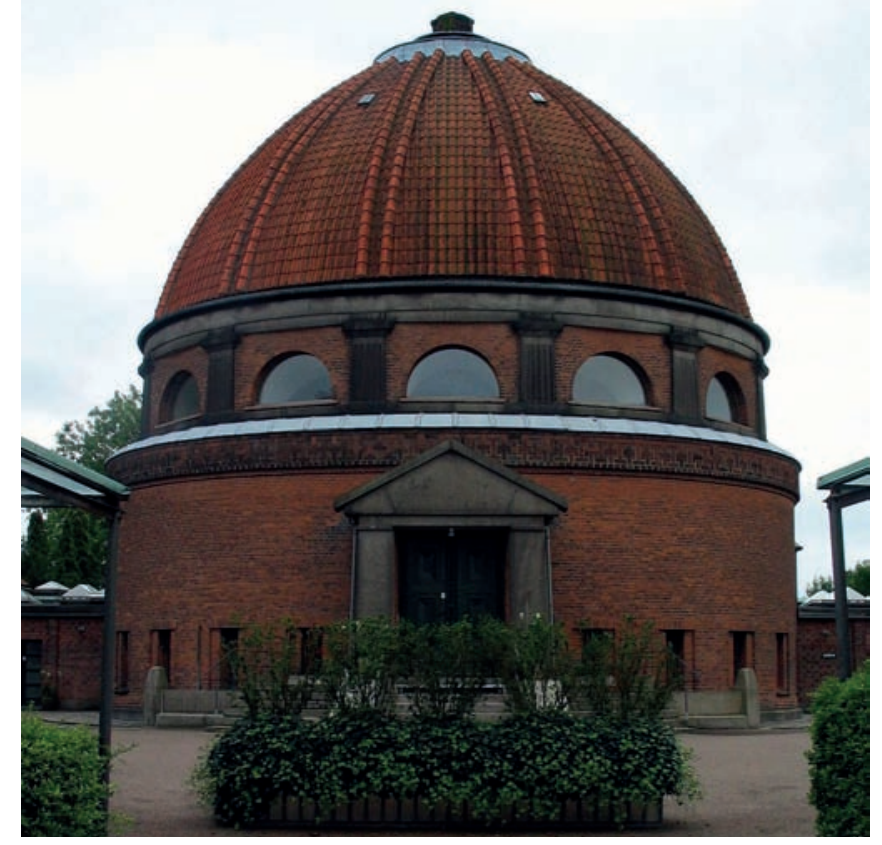

Рис. 3. Дания. Копенгаген. Крематорий. Архитектор Х. якобсен. 1905-1906 годы. Фото из открытых источников сети интернет

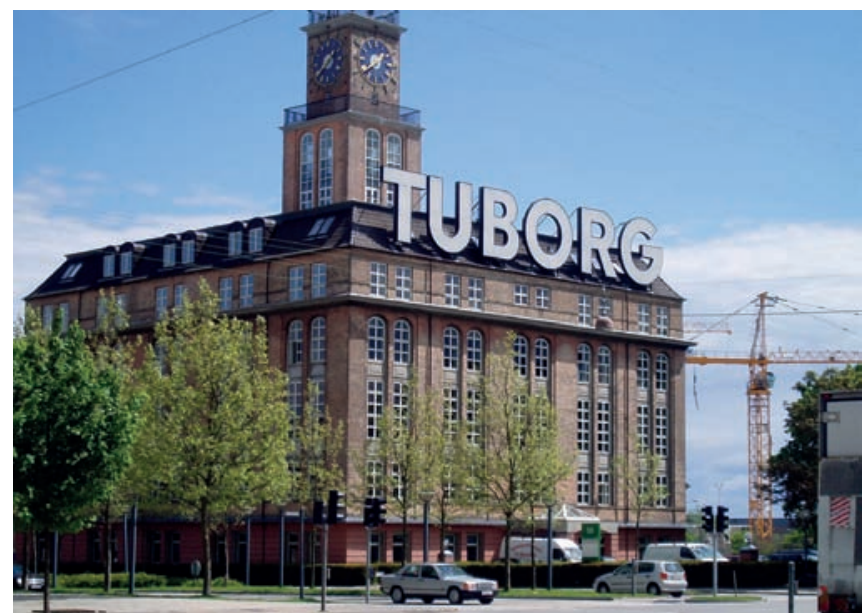

Рис. 4. Голландия. Амстердам. Завод «Туборг». Архитектор С. Рисом. 1923 год. Фото из открытых источников сети интернет

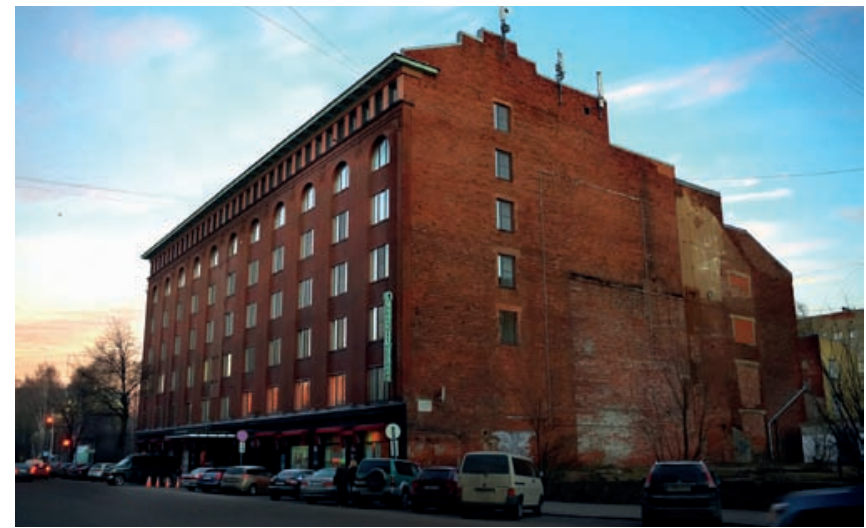

Рис. 5. Россия. Выборг. Редакция «Карельской типографии». Архитектор У. Ульберг. 1925-1929 годы. Фото из открытых источников сети интернет 
ционализма. Таково здание Художественного музея Выборга и здание городского архива ${ }^{12}$, спроектированные в 1930 году. Здание архива имеет кубические очертания и производит впечатление простой и ясной геометрической формы, однозначность этого впечатления опровергается оригинальными

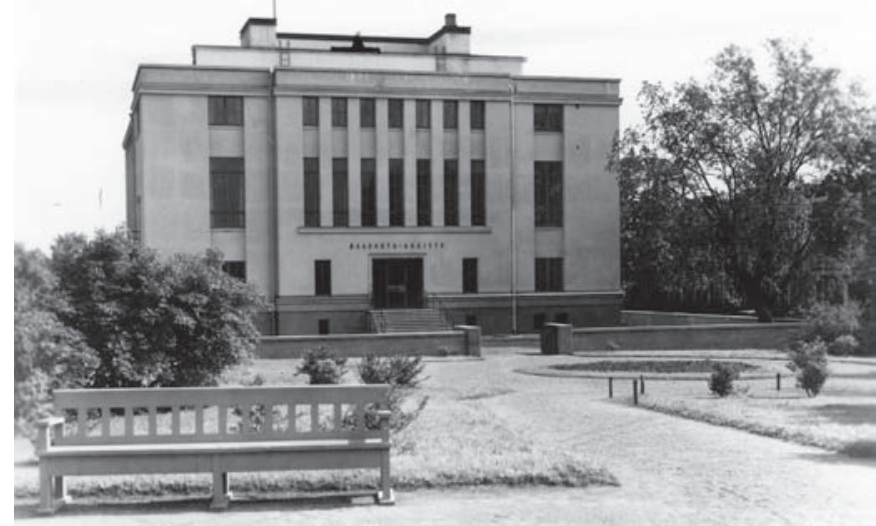

Рис. 6. Россия. Выборг. Городской архив. Архитектор У. Ульберг. 1930-е годы. Фото из открытых источников сети интернет

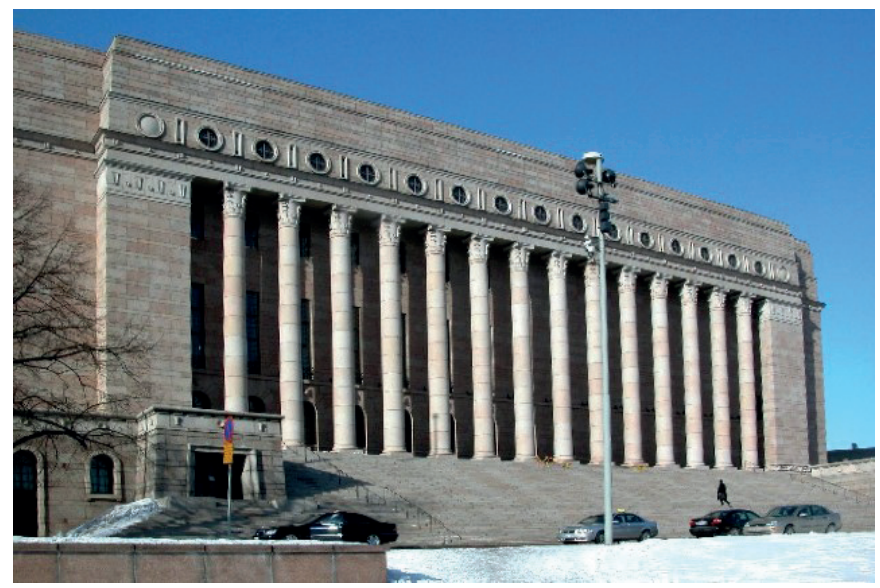

Рис. 7. Финляндия. Хельсинки. Здание парламента. Архитектор Й. Сирен. Проект 1924 года. Фото из открытых источников сети интернет

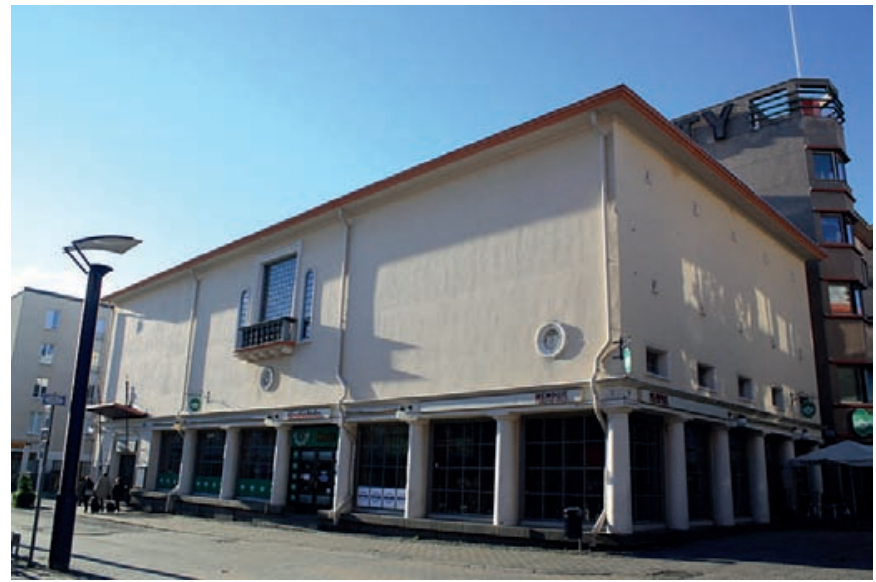

Рис. 8. Финляндия. Ювяскюль. Рабочий клуб. Архитектор А. Аалто. 1924 год. Фото из открытых источников сети интернет вертикалями световых проёмов. Здание архива выполнено в духе функционализма с элементами неоклассики в декоративных решениях (пилястры, легкие карнизы и т.д.) (рис. 6).

Главное здание в стиле нордического классицизма в Хельсинки - парламент (архитектор Й. Сирен ${ }^{13}$ ) (рис. 7). На создание проекта был объявлен архитектурный конкурс в 1924 году, в котором участвовали практически все именитые финские архитекторы, выиграл конкурс Й. Сирен. Фасад структурирован гигантской колоннадой из четырнадцати колонн коринфского ордера. Глубину пространства создаёт лоджия за колоннами. К входной зоне между колоннами ведёт большая лестница во всю ширину колоннады. Здание стоит на высоком рустованном цоколе. Антаблемент украшен несколькими карнизами и рядом круглых окон [1].

Самый известный финский архитектор первой половины XX века А. Аалто на заре карьеры работал в стиле нордического классицизма. Ранняя карьера А. Аалто начинается параллельно с быстрым экономическим ростом и индустриализацией Финляндии. Начиная с 1920-х, и до 1970-х годов шла творческая эволюция мастера: от скандинавского классицизма ранних работ, до рационального модернизма в 1930-1940. Первой зрелой работой в стиле нордического классицизма был конкурсный проект здания библиотеки в Выборге 1927 года, однако позднее под влиянием идей модернизма архитектор переработал проект [2]. Постройкой, выполненной в данном стиле, является рабочий клуб Ювяскюля (1924), план здания запроектирован по классицистическим законам, на фасаде в процессе строительства многие неоклассические элементы, предусмотренные в проекте, были отброшены. На А. Аалто большое впечатление произвела поездка в Италию, во время которой он познакомился с творчеством Л.-Б. Альберти, и в проекте рабочего клуба буквально использовал фрагменты его архитектурных решений (рис. 8). Так, в частности, в главном фойе клуба расположен круглый архитектурный объём, внешне решённый по композиционной и орнаментальной аналогии с фасадным, инкрустационным решением церкви Санта-МарияНовелла во Флоренции (Л.-Б. Альберти, 1456-1470). В 1926 году А. Аалто строит здание министерства обороны в Южной Остроботнии. Полуподземный цокольный этаж с круглым актовым залом, фойе и гардеробом построен из камня; верхние этажи из дерева. Фасад с пилястрами и часть интерьеров по проекту были ярко окрашены в стиле помпеянских интерьеров. После 1930 года архитектор сменил курс в проектировании на модернизм, однако ранние работы говорят об искренней увлечённости архитектурой Возрождения и если не творчеством А. Палладио непосредственно, то общей теоретической программой данного периода.

12 Для полноценного выполнения необходимых функций по хранению документов архитектором было предусмотрено множество конструктивных особенностей: специальная система вентиляции и отопления помещений, стеклянные перегородки на железном каркасе, полы с резиновым покрытием, металлические двери и оконные рамы с армированными стёклами.

13 Й. Сирен (1889-1961), финский архитектор. 
Коллега и соратник А. Аалто - Э. Бриггман ${ }^{14}$, его основные работы были выполнены для города Турку. В начале 1920-х годов архитектор приобрёл известность в Финляндии благодаря своим домам, выполненным в стиле нордического классицизма. Среди его наиболее заметных работ того периода постройки в центре Турку, в частности, отель «Сеорахуоне» (1927-1928), жилой дом «Атриум» (1925-1927) и прямо напротив него - отель «Хоспитс Бетель» (1926-1929) (рис. 9), между которыми зодчим разработан небольшой, но в то же время монументальный лестничный переход и площадь. Все три постройки расположены друг за другом на естественном рельефе холма, внешний вид фасадов объединен ритмом окон и лёгкими лоджиями в первыхэтажах. Со стороны улицы на фасадах использует тосканский ордер, на противоположном фасаде, выходящем в переулок, - вариация на тему коринфского ордера, но в очень вольном ключе с египтизирующими мотивами.

Стиль проявлялся не только жилом и общественном строительстве, примером его в культовом объекте можно считать лютеранскую церковь Тёёлё в районе Така-Тёёлё в Хельсинки (архитектор Г. Экелунд ${ }^{15}$, 1930) (рис. 10). Здание представляет собой пример зрелого стиля нордического классицизма, на фасаде можно увидеть ордерные детали - круглые таблетки-медальоны, пятиярусную аркаду в невысоком рельефе в центральной части. При этом форма входного портала напоминает обрамление входа древнеегипетских храмов. Центральная часть выделена декоративной конструкцией трёхчастной глубокой лоджии, установленной на плоской кровле. Лоджия является основанием для креста.

В Норвегии постройки в стиле нордического классицизма немногочисленны, они, как правило, соединяют стилистические концепции нескольких стран (Дании, Швеции и Норвегии). Г. Мунте-Каас ${ }^{16}$ был мастером норвежской архитектуры, творчество которого олицетворяет собой соединение разных традиций. Реализованный проект ратуши Хаугесунда был создан в 1922 году совместно с архитектором Г. Блакстадом ${ }^{17}$. Датой

14 Э. Бриггман (1891-1955), финский архитектор.

${ }^{15}$ Г. Экелунд (1893-1984). Его карьера как архитектора охватывает смену стилей в Финляндии - от скандинавского классицизма 1920-х годов до модернизма 1970-х.

${ }^{16}$ Герман Мунте-Каас (1890-1977), норвежский архитектор. Выпускник Университетского колледжа Осло, учился в Королевском технологическом институте в Стокгольме, а в 1919-1920 годы в Академии художеств в Копенгагене.

${ }^{17}$ Г. Блакстад (1893-1985), норвежский архитектор, с 1922 года начал свою собственную практику в Осло вместе с Арнштейном Арнебергом и Германом Мунте-Каасом. Он будет поддерживать партнёрские отношения с Германом Мунте-Каасом в архитектурной фирме более 50 лет. В период 1922-1960-х годов они участвовали в 66-ти конкурсах, завоевали призы в 33-х из них, из которых 22 были первыми призами. Фирма прекратила свою деятельность в 1989 году.

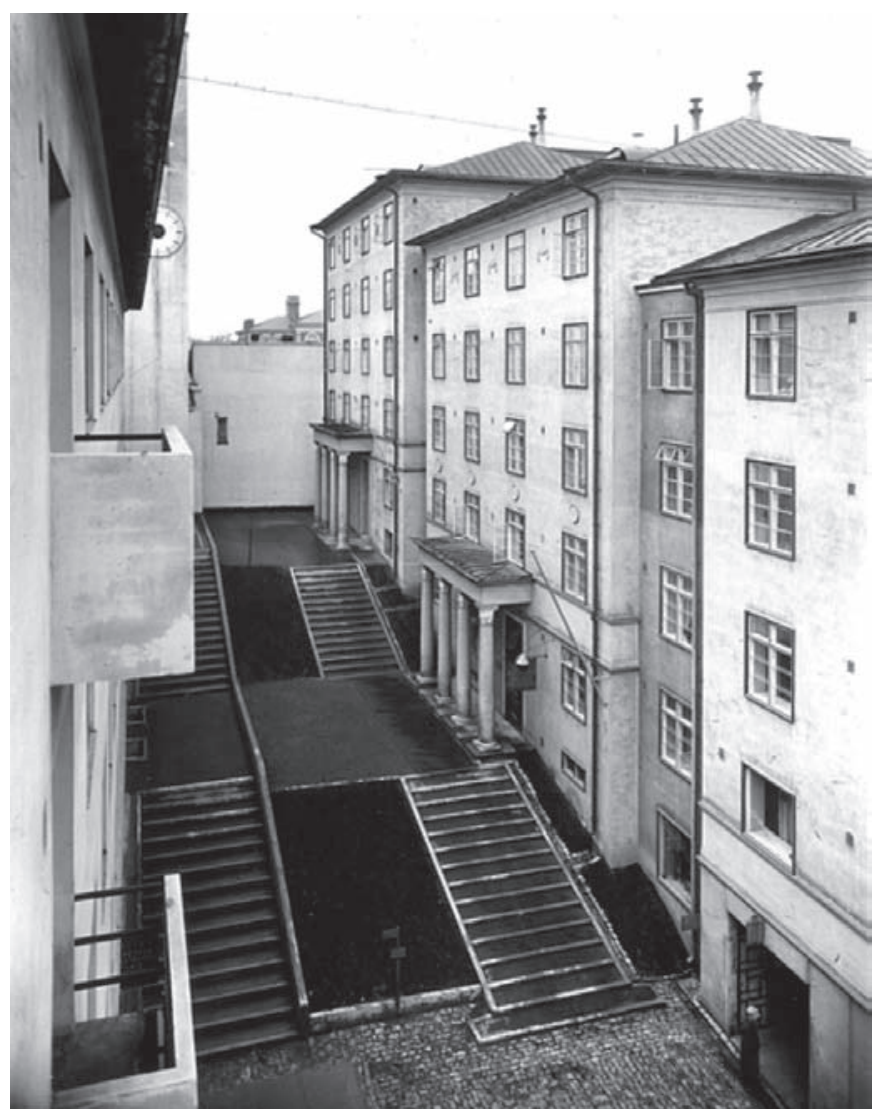

Рис. 9. Финляндия. Турку. Городское пространство. Архитектор Э. Бриггманн. 1925-1929 годы. Фото из открытых источников сети интернет

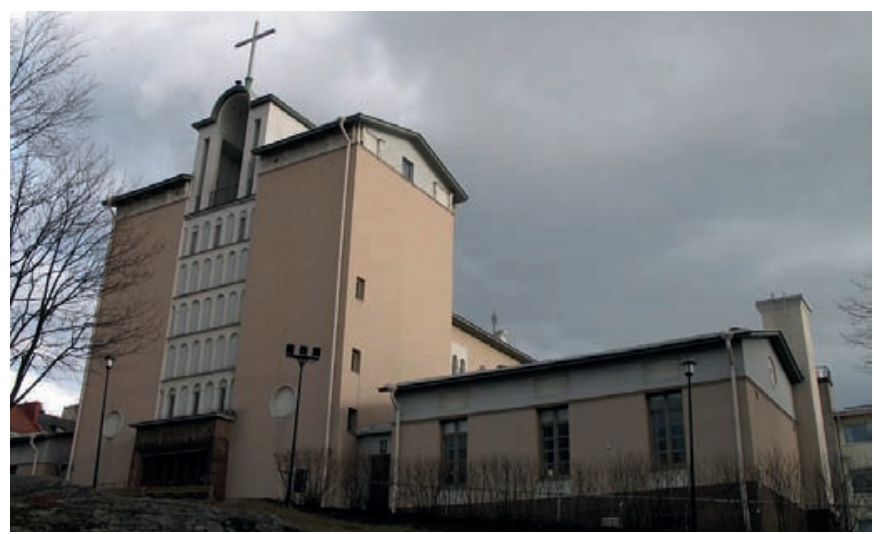

Рис. 10. Финляндия. Хельсинки. Лютеранская церковь Тёёлё. Архитектор Г. Экелунг. 1930 год. Фото из открытых источников сети интернет

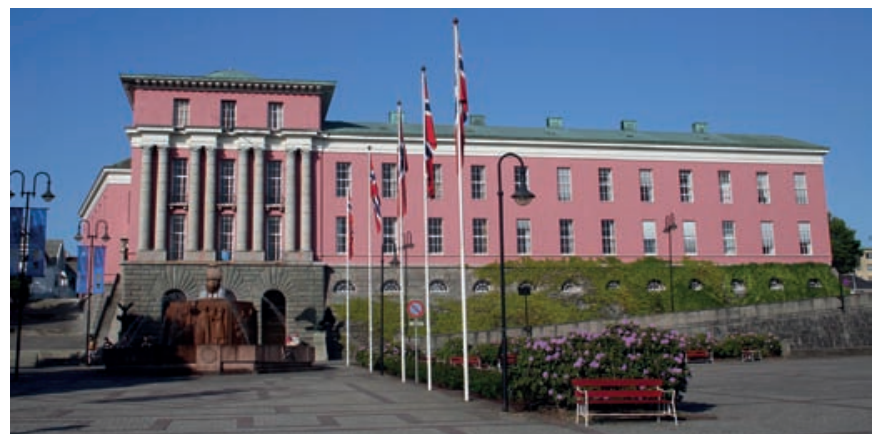

Рис. 11. Норвегия. Ратуша Хаугесунда. Архитектор Г. Мунmе-Каaс. 1922-1931 годы. Фото из открытых источников сети интернет 
окончания строительства называют 1931 год. Здание поражает совокупностью классицистических черт и приёмов. В этом смысле это, вероятно, самая насыщенная реминисценциями постройка в скандинавских странах (рис. 11). Мы видим контраст протяжённой плоскости фасада с мощным ассиметричным ризалитом, расположенные попарно сдвоенные колонны тосканского ордера. Цокольный этаж украшен рустом, карниз сильно раскрепован и вынесен. Здание производит торжественное и внушительное впечатление. Белые детали ордера эффектно контрастируют с красным цветом фасада.

В Норвегии многие здания в стиле нордического классицизма имеют специфическое функциональное назначение, например архитектор Л. Харбо Ри ${ }^{18}$ построил в данном стиле электростанцию в Бускеруде (1925). Композиция фасада решена ритмом гигантских арок, в которых расположены огромные окна. Мощный карниз задаёт зданию монументальный масштаб и увеличивает титаническое впечатление (рис. 12). Здание расположено на берегу и хорошо видно с воды, фасад имеет протяжённое развитие вдоль берега, масштаб деталей рассчитан

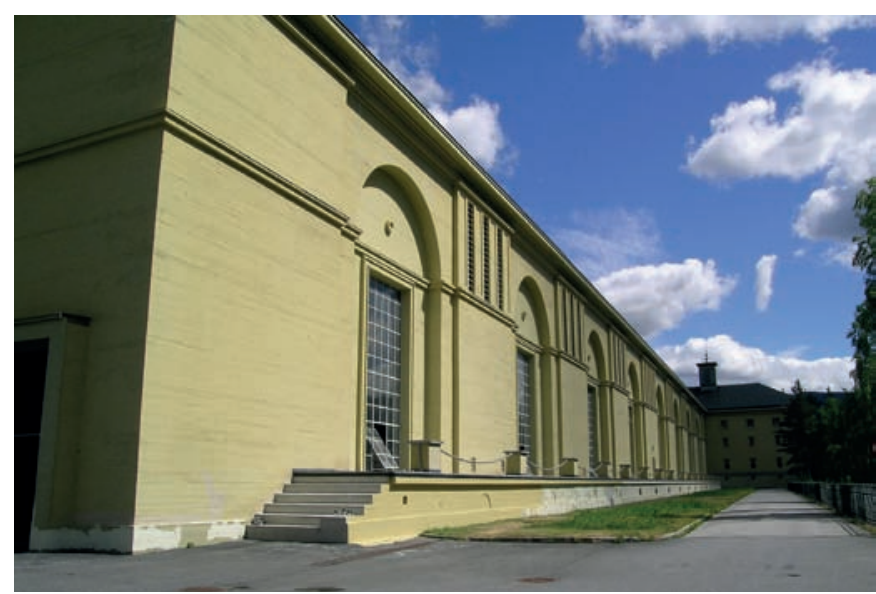

Рис. 12. Норвегия. Электростанция в Бускеруде. Архитектор Л. Харбо Ри. 1925 год. Фото из открытых источников сети интернет

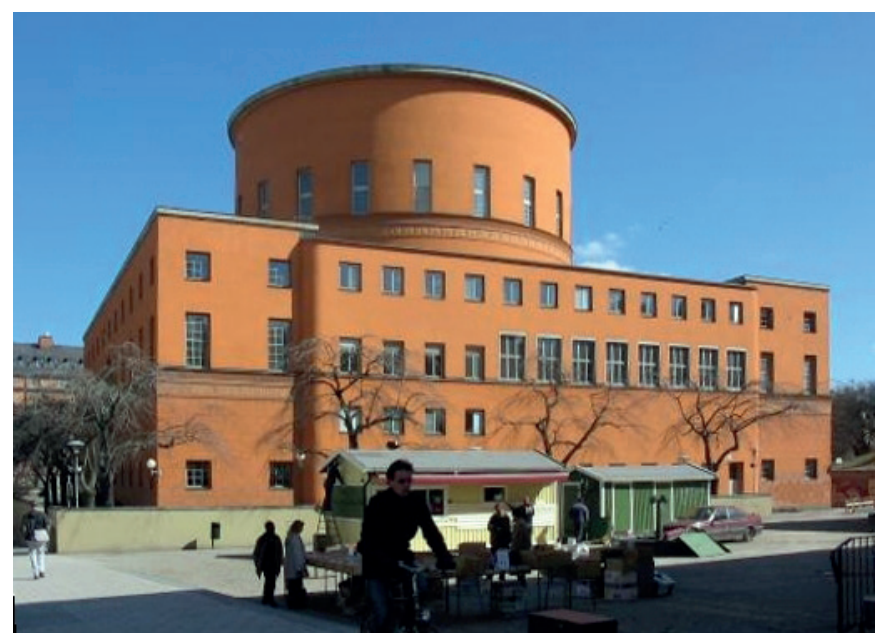

Рис. 13. Швеция. Стокгольм. Городская публичная библиотека. Архитектор Э.Г. Асплунд. 1924-1928 годы. Фото из открытых источников сети интернет на восприятие с большого расстояния, что позволяет провести аналогию с архитектурой церквей А. Палладио в Венеции.

Н. Биир ${ }^{19}$ пошёл ещё дальше: он создал ансамбль студенческого общежития в Осло по мотивам палладианских вилл. Центральное здание с фронтоном, расположенное на главной оси всего ансамбля, доминирует, к нему ведёт широкая парадная лестница. По сторонам от него два более низких корпуса (по типу баркесс на виллах А. Палладио). Комплекс построек дополняет окружающий их парк.

Особенность шведской архитектуры 1910-1930 годов по сравнению с другими скандинавскими странами - сильное влияние стиля национального романтизма. В Швеции построен ряд зданий с использованием неоготических мотивов и специфических черт архитектуры шведского ренессанса. На этом фоне построек нордического классицизма немного. Самое знаменитое здание в стиле романтического неоготического направления - главная ратуша Стокгольма, архитектор Р. 0стберг ${ }^{20}$. Он же - автор Морского музея в Стокгольме (1933-1936), выстроенного в стиле нордического классицизма. Протяжённое, мягко изогнутое здание с акцентом в центральной части в виде круглого башнеобразного объёма (напоминает маяк) с центральным входом, построено в парке на месте, где проходила Стокгольмская выставка (1930).

Э. Асплунд ${ }^{21}$ известен как ключевой представитель северного классицизма 1920-х годов. Со временем стал постепенно переходить к модернизму и функционализму, что окончательно утвердил на Стокгольмской международной выставке. Среди наиболее важных работ Э.Г. Асплунда - Стокгольмская публичная библиотека, построенная между 1924 и 1928 годами. Здание отсылает своими архитектурными решениями к классицизму в творчестве Э. Буле и Н. Леду. Крупные архитектурные объёмы составляют определённую «грацию» масс и ритмов (рис. 13). Постройка окрашена в яркий терракотовый цвет, что добавляет массивности очертаниям и демонстрирует применение активного цвета в постройках нордического классицизма. В сотрудничестве с архитектором С. Леверентцем ${ }^{22}$ спроектировал комплекс кладбища «Скугсчюркогорден», которое является объектом всемирного наследия ЮНЕСК0, созданного между 1914-ым и 1940-ым годами.

18 Л. Харбо Ри (1888-1962), норвежский архитектор. Большинство спроектированных им зданий построены в районах Осло Фрогнер и СанктХансхауген, а также в районе Бислетт. Предпочитал неоклассический стиль. За проект Музея Вигеланда (Vigeland-museet) был вместе с Карлом Бухом награждён в 1926 году премией Фонда Хоуэна.

${ }^{19}$ Н. Биир (1885-1950), норвежский архитектор.

${ }^{20}$ Р. Остберг (1866-1945), шведский архитектор, принадлежал к старшему поколению нордических классицистов, самая известная его постройка Главная ратуша в Стокгольме (1923) - относится к стилю национального романтизма.

${ }^{21}$ Э. Асплунд (1885-1940), шведский архитектор, с 1931 года был профессором архитектуры в Королевском технологическом институте. Его назначение было отмечено лекцией, позже опубликованной под названием «Наша архитектурная концепция пространства».

${ }^{22}$ С. Леверентц (1885-1975), шведский архитектор. Совершил позднее учебные поездки по Австрии и Италии, где увлёкся неоклассицизмом и творчеством К. Шинкеля. 
Кладбище расположено на холмистой местности в южной части Стокгольма. Используя естественный ландшафт, архитекторы создали очень живописное место. В ландшафт органически вписаны малые архитектурные формы построек (мавзолеи, храмы, памятники, малые некрополи), это решение представляет собой новое слово в архитектуре некрополей. В большинстве построек присутствуют отсылки к различным типам греческих и римских построек (пантеоны, мавзолеи, храмы) с применением образного декоративного ряда нордического классицизма с его универсализацией и упрощением некоторых элементов.

Э. Асплунд и С. Леверентц были главными архитекторами Стокгольмской международной выставки ${ }^{23}$ (1930). Выставка имела большое значение в истории архитектуры, прочно утвердив функционализм в качестве доминирующего архитектурного стиля в скандинавских странах. В 1930 году творческий стиль Э.Г. Асплунда резко переходит в сухой и решительный функционализм.

Шведский архитектор И. Тенгбом²4 был одним из самых известных представителей шведской неоклассической архитектуры 1910-х - 1920-х годов. В 1920-х годах создал проект здания Стокгольмской школы экономики (1925) и Стокгольмского концертного зала (1923-1926) на площади Хёторгет. Участвовал в создании проекта Стокгольмской публичной библиотеки совместно с Э. Асплундом. Концертный зал, вероятно, является самой известной постройкой в стиле нордического классицизма (рис. 14). Монументальное здание с цельным главным фасадом, главным украшением является гигантская колоннада коринфского ордера. Боковые фасады не имеют ордерных элементов декора, организация их композиции выполнена с помощью окон разных форм и размеров. Здание имеет плоскую кровлю, в верхней части фасада по всему периметру идёт карниз, символизирующий капительное завершение всего объёма.

Архитектор чье имя ассоциируется с одним только городом Упсала, стал Г. Лече 25 . В двадцать восемь лет он официально стал главным архитектором города, сильно повлияв на его архитектурный облик, спроектировал районы Тунабаккар (1947-1950) и Салабакке (1949-1953), а также много домов в Лютагене, Кунгсангене, Фьярдингене, Хоганасе и Фалхагене. Одним из первых зданий, построенных им в Упсале, стала школа Ваксаласколан (1925-1927), расположенная на площади Ваксала в Упсале. Здание в плане и на фасадах полностью опирается на палладианскую традицию. План представляет собой П-образную структуру (структура виллы с баркессами), однако средняя сто-

\footnotetext{
${ }^{23}$ Альвар Аалто, описывая выставку для финской прессы, писал: «Выставка выступает за радостную и спонтанную повседневную жизнь. И последовательно пропагандирует здоровый и непритязательный образ жизни, основанный на экономических реалиях».

${ }^{24}$ И. Тенгбом (1878-1968), шведский архитектор, работал в 1906-1912 годах с Эрнстом Торульфом в Стокгольме и Гётеборге. Он был назначен архитектором в Канцелярии главного интенданта в 1906 году и профессором архитектуры в Королевском шведском колледже искусств в 1916 году. Стал членом Королевской шведской академии художеств в 1917 году. В 1921 году был назначен генеральным директором Государственного управления строительства (Byggnadsstyrelsen).

${ }^{25}$ Г. Лече (1891-1954), шведский архитектор. Городской архитектор Упсалы в 1920-1954 годы.
}

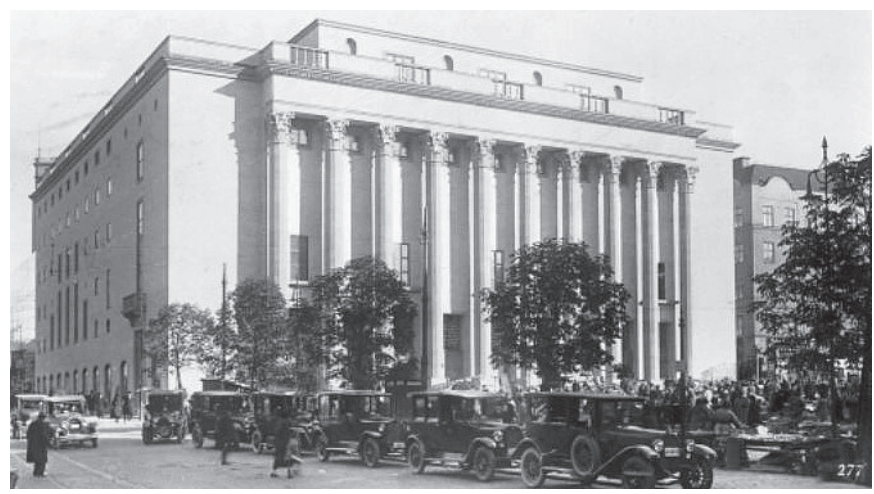

Рис. 14. Швеция. Стокгольм. Концертны зал. Архитектор И. Тенгбом. 1923-1926 годы. Фото из открытых источников сети интернет

рона, выходящая на площадь, ниже, чем два перпендикулярных к ней крыла. Архитектор использует весь арсенал приёмов Ренессанса - углублённые полукруглые ниши, большие окна с включением ордера, тему термального окна. Здание окрашено в зелёный цвет с контрастными белыми декоративными деталями. Производит впечатление лёгкости и изящества.

Появление в скандинавских странах стиля нордического классицизма в целом не было изолированным явлением, подобное обращение к неоклассическому наследию можно наблюдать в 1910-1920 годы во многих странах. Однако интересно проследить вариативность прочтения стиля в работах архитекторов четырёх стран. Эта неоднородность была признаком не до конца сложившегося стилистического языка. Период отмечен активным поиском правильного выразительного пути в архитектуре, соответствующего духу времени. В этом смысле нордический классицизм явился своеобразным переходным звеном, но оставшееся проектное наследие демонстрирует высокое качество и мастерство архитекторов.

\section{Лumepamypa}

1. Ceferin $P$. Constructing a Legend: The International Exhibitions of Finnish Architecture 1957-1967 / Petra Ceferin. - Helsinki : SKS, 2003.

2. Norberg-Schulz, C. Nightlands: Nordic Building / Christian Norberg-Schulz. - Copenhagen : MIT Press, 1997. - 164 p.

3. Jump up to / Ola Wedebrunn (ed.) // Technology of Sensations. The Alvar Aalto Vyborg Library. - Copenhagen : DOCOMOM0, Royal Danish Academy of Fine Arts, 2004.

4. Trencher, M. Alvar Aalto Guide / Michael Trencher. - UK : Princeton Architectural Press, 1996. - 28 p.

5. Spens, M. Viipuri Library. Alvar Aalto / M. Spens. - London : Academy editions, 1994. - 72 p.

6. Quantrill, M. Finnish Architecture and the Modernist Tradition. - UK : Spon Press, 1998. - 74 p.

7. Alvar Aalto Library in Vyboorg: Saving a Modern Masterpiece / Helsinki : Rakennustieto, 2009.

8. Vaden, T. Artistic Research. Theories, Methods, and Practices / T. Vaden, M. Hannula, J. Suoranta. - Helsinki : Kuvataideakatemia, 2005. 
9. Schildt, G. Alvar Aalto in his Own Words / G. Schildt. Canada :Otava press, 1997. - $108 \mathrm{p}$.

10. Vium. N. Huak Kappman /. N Vium. - Copenhagen : Kunstindeks Danmark \& Weilbach Kunstnerleksikon, 2019.

11. Johnsen, E. Herman Munthe-Kaas / Johnsen. E. / Magazine "Norsk biografiskleksikon". Retrieved October 1, 2017.

12. Josephson, R. "Isak GustafClason". / Magazine "Svenskt biografisktlexicon". Retrieved April 1, 2019.

13. Шукурова, А.Н. Асплунд Эрик Гуннар // Большая российская энциклопедия : В 35 томах. Том 2. - М., 2005. - С. 369-370.

14. Иконников А.В. Хельсинки / А.В. Иконников. - Л. : Стройиздат. Ленинградское отделение, 1967.

15. Иконников А.В. Новая архитектура Финляндии / А.В, Иконников. - М. : Стройиздат, 1971. - 144 С.

16. Гозак А.П. Алвар Аалто / А.П. Гозак. - М. : Стройиздат, 1976.

17. Курбатов, Ю.И. Хельсинки / Ю.И. Курбатов; Изд. 2-е, перераб. и дополн - Л. : Искусство, 1985. ; Курбатов, Ю.И. Хельсинки. Образы города / Ю.И, Курбатов. - СПб : Коло, 2013. - 272 с.

18. Angeletti, A. Alvar Aalto e il Classicismo Nordico / A. Angeletti, G. Remiddi. - Rome : F.lli Palombi, 1998. ISBN 887621-666-9.

19. Jørgensen. $B$. Neoclassical Architecture in Copenhagen and Athens / B. Jørgensen, D. Porphyrios. - Athens : Olimp 1987.

20. Paavilainen, Simo and Juhani Pallasmaa. Nordic Classicism 1910-1930 / Simo Paavilainen, Juhani Pallasmaa. - Helsinki : Museum of Finnish Architecture, 1982. ISBN 951-9229-21-3.

21. Salokorpi, A. Classical Tradition and the Modern Movement / A. Salokorpi // Proceedings of the International Alvar Aalto Symposium, 2. - Helsinki : Finnish Association of Architects, 1985. (). ISBN 951-9229-38-8.

\section{References}

1. Ceferin P. Constructing a Legend: The International Exhibitions of Finnish Architecture 1957-1967. Helsinki, SKS, 2003. (In Engl.)

2. Norberg-Schulz C. Nightlands: Nordic Building. Copenhagen, MIT Press, 1997, 164 p. (In Engl.)

3. Ola Wedebrunn (ed.). Jump up to. In: Technology of Sensations. The Alvar Aalto Vyborg Library. Copenhagen, DOCOMOM0, Royal Danish Academy of Fine Arts, 2004. (In Engl.)

4. Trencher M. Alvar Aalto Guide. UK, Princeton Architectural Press, 1996, 28 p. (In Engl.)
5. Spens M. Viipuri Library. Alvar Aalto. London, Academy editions, 1994, 72 p. (In Engl.)

6. Quantrill M. Finnish Architecture and the Modernist Tradition. UK, Spon Press, 1998. 74 p. (In Engl.)

7. Alvar Aalto Library in Vyboorg: Saving a Modern Masterpiece. Helsinki, Rakennustieto, 2009. (In Engl.)

8. Vaden. T., Hannula. M., Suoranta. J. Artistic Research. Theories, Methods, and Practices. Helsinki, Kuvataideakatemia, 2005. (In Engl.)

9. Schildt G. Alvar Aalto in his Own Words. Canada, Otava press, 1997, 108 p. (In Engl.)

10. Vium N. Huak Kappman. Copenhagen, Kunstindeks Danmark \& Weilbach Kunstnerleksikon, 2019. (In Danish)

11. Johnsen, E. Herman Munthe-Kaas. In: Norsk biografisk leksikon, 2017, Retrieved October, no. 1. (In Engl.)

12. Josephson. R. Isak Gustaf Clason. In: Svenskt biografiskt lexicon, 2019, Retrieved April, no. 1. (In Swedish)

13. Shukurova, A.N. Asplund Erik Gunnar. In: Bol'shaya rossiiskaya entsiklopediya [Great Russian Encyclopedia], in 35 vol., Vol. 2. Moscow, 2005, pp. 369-370. (In Russ.)

14. Ikonnikov A.V. Khel'sinki [Helsinki]. Leningrad, Stroiizdat, Leningrad branch Publ., 1967. (In Russ.)

15. Ikonnikov A.V. Novaya arkhitektura Finlyandii [New architecture of Finland]. Moscow, Stroiizdat Publ., 1971, 144 p. (In Russ.)

16. Gozak A.P. Alvar Aalto. Moscow, Stroiizdat Publ., 1976. (In Russ.)

17. Kurbatov Yu.I. Helsinki. Leningrad, Iskusstvo Publ., 1985. (In Russ.); Kurbatov Yu. I. Khel'sinki. Obrazy goroda [Helsinki. Images of the city]. St. Petersburg, Kolo Publ., 2013, 272 p. (In Russ.)

18. Angeletti A., Remiddi G. Alvar Aalto e il Classicismo Nordico. Rome, F.lli Palombi, 1998. ISBN 88-7621-666-9. (In Ital.)

19. Jørgensen B., Porphyrios D. Neoclassical Architecture in Copenhagen and Athens. Athens, Olimp 1987. (In Engl.)

20. Paavilainen S., Pallasmaa J. Nordic Classicism 1910-1930. Helsinki, Museum of Finnish Architecture, 1982. ISBN 951-922921-3. (In Engl.)

21. Salokorpi A. Classical Tradition and the Modern Movement. In: Proceedings of the International Alvar Aalto Symposium, 2. Helsinki, Finnish Association of Architects, 1985. ISBN 951-9229-38-8. (In Engl.)

Цветкова Полина Олеговна (Москва). Кандидат искусствоведения. Доцент кафедры «Истории и теории декоративного искусства и дизайна» ФГБОУ В0 «Московская государственная художественно-промышленная академия им. С.Г. Строганова» (125080, Москва, Волоколамское шоссе, 9. МГХПА им. С. Г. Строганова). Эл. почта: tsvetkovap@gmail.com.

Tsvetkova Polina 0. (Moscow). Candidate of Art History. Associate Professor at the Department of History and Theory of Decorative Arts and Design of Stroganov Moscow State Academy of Arts and Industry (9, Volokolamskoe highway, Moscow, 125080. MGHPA). E-mail: tsvetkovap@gmail.com. 